
FARMÁCIA NA GEÓRGIA ANTIGA E MEDIEVAL

\title{
THE HISTORY OF CHEMISTRY AND PHARMACY DEVELOPMENT IN EARLY AND MEDIEVAL GEORGIA
}

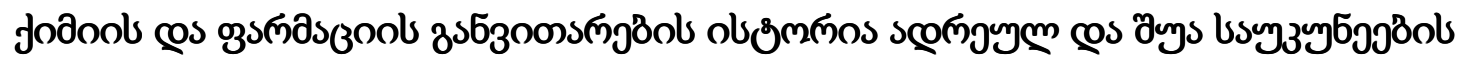

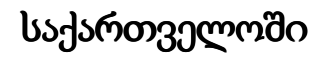 \\ KUPATADZE,Ketevan \\ Ilia State University, Georgia, Tbilisi \\ Kakutsa Cholokashvili Ave 3/5. Tbilisi 0162, Georgia \\ * Corresponding author \\ e-mail: Ketevan_kupatadze@iliauni.edu.ge
}

Received 27 November 2018; received in revised form 27 December 2018; accepted 27 December 2018

\section{RESUMO}

Este artigo analisa o desenvolvimento da química e da farmácia no período inicial e medieval da Geórgia. Vamos nos concentrar apenas nas direções principais. A informação apresentada em si é importante do ponto de vista histórico; no entanto, acreditamos que ele desempenha um papel igualmente significativo no processo de ensino de química. Vincular diferentes questões químicas à história de sua descoberta ou do seu desenvolvimento desperta interesse e disposição adicionais nos alunos. Uma vez que o clima é criado, nunca desaparece e, no futuro, uma boa base é garantida para a aprendizagem abrangente do tema.

Palavras-chave: História da Química; Química Didática; Química na Geórgia antiga e medieval.

\section{ABSTRACT}

This article reviews chemistry and pharmacy development in the early and medieval period of Georgia. We will focus only on key directions. The presented information itself is important in historical point of view; however, we believe, that it plays an equally significant role in the chemistry teaching process as well. Linking different chemical issues to the history of its discovery or development kindles additional interest and disposition in students. Once the mood is created, it never fades away and in the future, a good basis is ensured for comprehensive learning of the topic.

Keywords: History of chemistry; Chemistry Didactic; Chemistry in early and medieval Georgia;

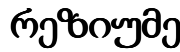

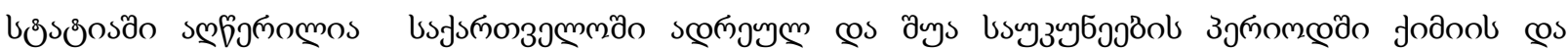

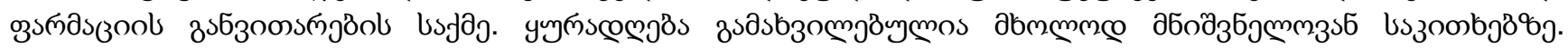

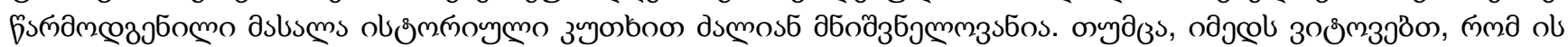

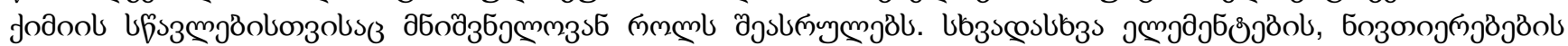

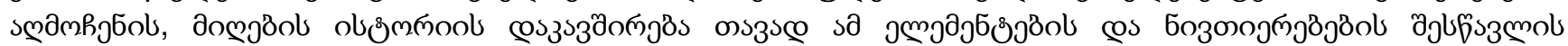

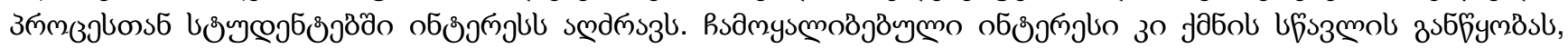

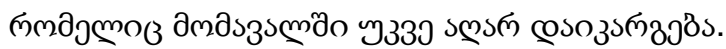

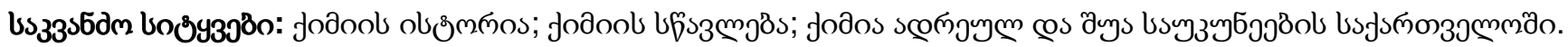




\section{INTRODUCTION}

In Georgian literature Chemistry was first mentioned in the 10th-century monument translated from Greek into Georgian by Ekvtime Mtatsmindeli, referring to the life of St. Bagrat. The book contains notions of metallurgy and chemistry. However, the 10th century, that was believed to be the date when the name "chemistry" first appeared in Georgian literature, should be considered conditional, as it might have as well been mentioned even before, but the source may have not survived to our times.

There are written sources claiming that Georgian tribes dwelling in Asia Minor had a welldeveloped practical knowledge of Chemistry. From these ancient tribes, Tabals, Saspers, Mushkis, Chalybes, Iberians were considered to be culturally more advanced, followed by Colchians and Lazi people, Mingrelian-Chani tribes and Svans on a later stage. Apollonius Rhodius writes [1]: "The Chalybes were not engaged in farming, fruit-growing or cattlebreeding. They would rather dig the gloomy ironrich ground and exchanged the extracted iron-ore for grocery". S. Kaukhchishvili provides the data about Georgian tribes of the antique epoch and confirms that Georgian tribes: Kolkhi, Lazi, etc, dwelled closed to the Black Sea that time and were skilled in ore extraction.

The era of practical chemistry is related to stone extraction and processing. According to archaeological excavations, rock, brick, and tile were used as the construction materials in ancient Georgia. They had developed their own, original Iberian rule of tile production, that was especially advanced in I century B.C when Mtskheta was the capital of Iberia [1]. Most significantly, "The Book of Secrets" by Muhammad ibn Zakariya Al-Razi [2] reads about a variety of clay, differentiating between porcelain, horticultural, crucible, firm white clay, etc. The third volume of "Medicine Treatise" by Ibn Sina [3], names up to twenty different clays. That means that before these prominent representatives of Arabian alchemistry, clay and the rules of working with it were already wellknown in Georgia.

In his book, Al -Razi mentions about enameling the surface of the ceramic vessel. In the period of practical chemistry, this technique was well practiced in Georgia and they knew that through this technique: a) enameling can prevent water leakage from clay vessels and b) enameling is desirable for dressing up clay items. To this end they used to apply quartz- $\mathrm{SiO}_{2}$, feldspar $-\mathrm{K}_{2} \mathrm{O} \cdot \mathrm{Al}_{2} \mathrm{O}_{3} \cdot 6 \mathrm{SiO}$, soda- $\mathrm{Na}_{2} \mathrm{CO}_{3} \cdot 10 \mathrm{H}_{2} \mathrm{O}$, potash- $\mathrm{K}_{2} \mathrm{CO}_{3}$, saltpeter- $\mathrm{KNO}_{3}$, borax $\mathrm{Na}_{2} \mathrm{~B}_{4} \mathrm{O}_{7} \cdot 10 \mathrm{H}_{2} \mathrm{O}$.

According to the selected material, glazing would consist of the following silicates: $\mathrm{K}_{2} \mathrm{SiO}_{3}$ (ie, $\mathrm{K}_{2} \mathrm{O} \cdot \mathrm{SiO}_{2}$ ), $\mathrm{CaSiO}_{3}$ (ie, $\mathrm{CaO} \cdot \mathrm{SiO}_{2}$ ), $\mathrm{Na}_{2} \mathrm{SiO}_{3}$ (ie, $\mathrm{Na}_{2} \mathrm{O} \cdot \mathrm{SiO}_{2}$ ), $\quad \mathrm{PbSiO}_{3}$ (ie, $\mathrm{PbO} \cdot \mathrm{SiO}_{2}$ ), $\mathrm{Al}_{2}\left(\mathrm{SiO}_{3}\right)_{3} \quad$ (ie, $\mathrm{Al}_{2} \mathrm{O}_{3} \cdot 3 \mathrm{SiO}_{2}$ ). However, the chemical composition of silicates was unknown to them. The main thing was to ensure that the material was firmly attached to the wall of clay vessel and it was prevented from cracking.

The vessel found in Dmanisi excavations [4] is marked by two kinds of glazing: a) transparent glass-like, consisting of lead oxide - $\mathrm{PbO}$, quartz $\mathrm{SiO}_{2}$, and red lead $\mathrm{Pb}_{3} \mathrm{O}_{4} ;$ b) colorful vitreous glazing, that in addition to lead and silicon oxides, contains copper (II) oxide-CuO, giving a green shade to the glass. For a light pink color, they used a "black stone", i.e. manganese (II) oxide $\mathrm{MnO}_{2}$. In this case, light pink is not obtained from manganese (II) oxide, but from the manganese silicate $\mathrm{Mn}_{2}\left(\mathrm{SiO}_{3}\right)_{3}$, generated as a result of chemical reactions.

$4 \mathrm{MnO}_{2} \rightarrow 2 \mathrm{Mn}_{2} \mathrm{O}_{3}+\mathrm{O}_{2}$

$\mathrm{Mn}_{2} \mathrm{O}_{3}+3 \mathrm{SiO}_{2} \rightarrow \mathrm{Mn}_{2}\left(\mathrm{SiO}_{3}\right)_{3}$.

$\left(500^{\circ} \mathrm{C}\right)$

The copper was discovered in the Eneolithic period and they shifted from stone to metal workmanship. Copper was found in Tergi ravine, in Kakheti, in Alaverdi (places in Georgia). In the same era, the foundation was laid for metallurgy development (III-II millennium BC). Virgin copper processing should be considered as its beginning. Copper smelting from oxygencontaining ores is a relatively easier process compared to its extraction from sulfide ores. Therefore, it can be assumed, that for the first time, copper was derived from processing red ore $\left(\mathrm{Cu}_{2} \mathrm{O}\right)$ or malachite $\mathrm{CuCO}_{3} \cdot \mathrm{Cu}(\mathrm{OH})_{2}$. Smeltingrecovery was achieved by heating charcoal at high temperature. However, the question arises: how the people of that time could have thought of this method, being completely ignorant of chemical processes. There is a version, that they could have obtained this technique out of curiosity and based on their own observations. For instance, copper was covered with greenish substance. The substance of this color, specifically, emerald malachite $\mathrm{CuCO}_{3} \cdot \mathrm{Cu}(\mathrm{OH})_{2}$ and blue azurite $\mathrm{CuCO}_{3} \cdot \mathrm{Cu}(\mathrm{OH})_{2}$ were also possible to find in the nature. Comparing these 
substances to the ores with similar color found in the nature could have led to the conclusion that the ores contain copper. The next step would be to get copper from the ore. They would be using fire, as it was the only source of energy. By the influence of fire, malachite or azurite would turn black. Of course, this black substance was a copper (II) oxide. People of those time could not have known that. However, the practice showed that it was possible to get copper from this black substance. Frist rust was generated from ores, out of which the metal was recovered by coal.

Giving the names to the existing metals is also very interesting. Iv. Javakhishvili $[5,6]$ considers, that in addition to tin, Georgian tribes have created metal names themselves and they aren't borrowed from any foreign languages. For example:

1. Gold -in Megrelian dialect is pronounced almost the same as in a literary language -OkroOrko; in Svanetian dialect: - Vkre; The name of gold can also be derived from Georgian word "inextinguishable" due to the fact, that the glittering of this metal never extinguishes, the surface of it never fades away.

2. Silver (vertskhli) - in Megrelian dialect is pronounced as varchkhli, in Svanetian varchkhil.

3. Copper (spilendzi) - Georgian tribe spinners, their ores - Spirendz-spilendz, in Svanetian - spilendz, in Megrelian - linj.

4. Iron (rkina), pronounced in Lazi language as -erkina, meaning the sky. In old times, they believed that the sky was made of iron.

5. Lead (tkvia) - pronounced as tkvivi, brpeni i.e. prpeni.

6. Only the name of Tin (pronounced as kala) is originated from city Kalah, located on Malaka peninsula, from where they used to acquire tin ores. First, this metal was brought to Iran - Tavriz, cold Kali-Kala in ancient times and then from there - directly to Georgia.

7. Brass (titberi) -copper and zinc alloy- is derived from Megrelian - tuta-color. In Megrelian, tuta means the moon.

8. Especially interesting is the name of Mercury (vertskhlistkali). The name of this element was first introduced by doctor Dioskoride in the Ist century in his work on "Remedies", providing the data on natural, animal and inorganic agents, including mercury. In the Greek language, its name is derived from Greek words water and silver. Roman Plinius (23-79yy) attached Latin suffix to this name, thus creating its modern international name - Hydrargyrum. Its Georgian name is found in "Unparagoned Karabaddin" by Kananeli. "Mercury" had also been used earlier in the Georgian language. According to I. Abuladze's [5] dictionary, "Mercury" was first mentioned in the $10^{\text {th }}$ century in the scripture by Grigol Noseli, with the following edition: "For the habit of the human body". The name of mercury -"Vertskhlis tskali (Silver water - translation)" proved to be pretty suitable and responding to external physical properties of this metal. Indeed, mercury is a liquid and therefore the name "tskali" - (water) is used. At the same time, "water" has a silver color, i.e. it is "silver water".

In the 1st millennium BC, the word "lime" (pronounced as "Kiri") appears in the Georgian language. It has been derived from Urartian language "Kira" i.e. Kiri, that means "soil". As the construction material, "lime" ("kiri") was introduced in Georgia in VIII-VII centuries BC. In his "Life of Kartli" Leonti Mroveli is writing the following: "Hitherto lime wasn't used in any construction work" [7,8]. After adding lime to the list of construction materials, it became possible to construct such architectural monuments that have survived centuries.

Lime reinforcement and consolidation is conditioned by four factors: 1 . Drying, 2 . Crystallization, 3 calcium carbonate formation from air interaction with carbon dioxide. 4 The interaction between lime and sand. The last two processes are more important but as they are carried out at a slow pace, lime gradually gets harder. In Georgian scientific literature, lime without water (oxide) is called "unextinguished", and lime with water content (hydroxide) is called extinguished. King Vakhtang VI (see the information below) used to call them as subsided and non-subsided [9].

According to archeologic excavations, glass production had also been developed in Georgia. Some sources attribute its emergence to IV-III centuries BC. Blue glass items found in Mtskheta local workshops must be of VI-V centuries [10]. It is also known that they used to melt cobalt and copper compounds to get colored glass. The archeological excavations prove that they were familiar with paint production techniques in the ancient and Middle Ages Georgia. Dmanisi masters would use yellow, orange color; 
turquoise color, green, whitish paints in ceramics. Chalk $-\mathrm{CaCO}_{3}$; barite- $\mathrm{BaSO}_{4}$, kaolin$\mathrm{Al}_{2} \mathrm{O}_{3} \cdot 2 \mathrm{SiO}_{2} \cdot 2 \mathrm{H}_{2} \mathrm{O}$ were widely utilized as white paint. Colorless dyes were prepared by alloying crushed glass with lead oxide and white sand (silicium (II) oxide). The mixture of Iron hydroxide and iron oxide was used as yellow paint. Antimony sulfide was also applied for the same purpose. For getting green dyes, they mainly used malachite and mixed it with copper (II) oxide, chromium (III) oxide, aluminum (III) oxide, and magnesium (II) oxide. For getting red paint, they used iron (III) oxide, vermilion (cinnabar in Georgian) HgS, in old times its suspension in water was frequently used as red ink.

The King Vakhtang's book "The Book on Mixing Oils and Making Chemistry" was written in 18 century and reached our times in a form of a manuscript containing 72 pages. The manuscript consists of 279 paragraphs; the text contains several draughts of chemical tools. It should be mentioned that under the term "oils" Vakhtang meant liquids of different ingredients. Thus the name of this book implies a chemical transformation through mixing different liquids.

According to D. Bregvadze, Vakhtang began to write his book in Isfahan and continued in Kerman and Russia. The book is written in the form of a practical textbook. It is not a simple translation. Along with data gathering, Vakhtang elaborated the rules of obtaining certain mixtures and elements based on his own observation and wide scientific knowledge [11].

By the way, in his book, King Vakhtang VI repeatedly writes about cinnabar, but only for the purpose of preparing a dye and never considering it as an elixir for gold transmutation.

Experiment \#42 was called- "Making the Cinnabar". \#48 describes the preparation of highquality cinnabar. For this purpose, iron sulfate $\left(\mathrm{FeSO}_{4}\right)$ should be added to sulfur and mercury. Prepared cinnabar needs to be sublimated. Vakhtang talked about quantitative measurements and wrote - "take two parts of sulfur and one part of mercury".

\#181describes even more complex method of cinnabar preparation, using the powder of sandalwood instead of sulfur, while Mercury has to be taken in double quantity. It should be underlined that cinnabar is the name of the native mineral. Red paint was produced from cinnabar, which was actively used for various purposes. Vakhtang had known this, as shown from his last two records; therefore, he was trying to get exactly cinnabar and not just salt. Nothing is mentioned about cinnabar's transformation into gold. Thus, Vakhtang used cinnabar as paint.

In N159 recipe, Vakhtang VI describes the process of preparing yellow ink: „There is a special type of a tree, one can find in riverside woods, its fruit is similar to an acorn. Smash it, soak it in lye, boil it, filter, then boil again and mix it with the pounded alum". Lye would probably be alkaline, and alum -aluminum sulphide. As for the acorn-like fruit, the king is probably referring to "Gall's Nuts", used for ink preparation during Arab alchemy period. These Nuts contained tannin acids. In 1862, Michael de Champoner and M. Malepayer published the following recipe in the "Dictionary of Chemistry": a string of Aleppo oak nuts (battered) - 8 ounce (226.796 grams); black sandalwood tree crust- 4 ounces; iron sulphate - 4 ounces, Acacia resin -gum Arabic - 3 ounces; copper sulphate - 1 ounce; Crystalline sugar-1 ounce. Put Gall's Nuts in 5liter water and let it boil for an hour, or, until half of the water evaporates. Filter the received solution and add the remaining ingredients to the filtrate until getting viscous liquid. Leave it for 24 hours, place it in dark vessel, cover firmly and store.

Another recipe is as follows: "Pound 4 ounce ( 1 ounce $=28.3495 \mathrm{gr}$ ) of Allepo oak nuts (strings) in a porcelain mortar, add one ounce of the crushed crust of the same tree and pour 3 pints (1 pint -1.41953 I.) of soft water. Boil it on a low temperature until it becomes half. Then, add 2 ounces of iron sulphate, $1 / 2$ ounce of blue vitriol or copper carbonate (the latter is better), 2 ounces of Acacia resin -gum Arabic and 2 ounces of brown sugar. Shake well and leave it for a week. Then filter and add a small amount of alcohol, the ink is ready.

Chemistry in Georgia was not only used for household needs, but it also facilitated the future pharmacy and medicine development. Medical handbooks having survived to our times indicate the abovementioned. The term - Karabaddin Akrabaddin - the medical book is originated from Arabic "Aqrabadin" that means a little book, booklet [12]. "Unparagoned Karabaddin" ("unparagoned" - matchless, the most correct) is a remarkable monument of XI century. It's influenced by Arabic and Persian medicine, however, one can also find there examples of Georgian public medicine. The author also describes his own observations [13]. According to 
"Karabaddin", from the four elements of Greek people, blood in the human body corresponds to water, grief corresponds to the soil, gall (stomach juice) - to fire, vomited bile -to air. When the balance among them is breached, or any of them becomes useless, then the disease emerges. The author builds his methods upon the principle of contradiction. He directs the cool against the warm; the warm is used against the cool; dry is directed against the moist; moist is used against dry.

The former Hodja agrees with the above mentioned in Karabaddin and provides a number of folk methods and medicines nowadays still used in folk medicine. In his "Medical Book" Zaza Panaskerteli-Tsitsishvili builds all treatment methods upon the doctrine of four elements. However, along with Iranian-Arabic influence, the influence of Christian religion can also be perceived. Another significant medical book is "ladigar Daudia", written by David Bagrationi (King of Georgia) when being in Istanbul in 15691578. The author shares the idea of four elements - water, soil, air, and fire. Georgian medical handbooks frequently mention different units of weight used in eastern countries. 1. Zolotnik-4,25gr. 2. Ounce--30,0gr; 3. Carat0,33gr; Farthing-1,0495gr; 4.Bowl - a modern teacup;

One can find medicine names in "ladigar Daud" that differ from Georgian modern names; "Kveraki" - a pill, "Ghati"- gastrointestinal medicine; "Guarishni"-remedy for digestion, lariji/plaster - ointment; "Sikangubin"- cure for liver; "Sharbati" - syrup; "Mughlab"-fluid medicine; "Tle" - compression; Wine is referred to as one of the cures and very often it represents a component for drug preparation.

Vakhtang the VI speaks about "Oils" in his book $[14,15]$. The notion "oil" is not used with its modern sense. The "oils" described in the book should probably be referred to as ointments. The king used sulfur for preparing most of the "oils". Sometimes he used to mix soap water with them. In some cases, the king would also add lime or mercury salt to it (mercurial - i.e. a salt of mercury). Vakhtang the VI writes the following about such "oils": "There is nothing better for pimple treatment than the "oil"; Sometimes he advises to prepare "oil" from sulfur, ammonium chloride, and ash. In all the cases, where oil was made of sulfur with soap water, unsubsided lime or ash, mainly the chemical reaction was represented by sulfur and alkaline interaction, as a result of which sodium - or calcium sulphide or polysulfide was formed. Such materials were even used in more advanced medicine for skin disease treatment, such as mange.

$$
\begin{aligned}
& 6 \mathrm{NaOH}+3 \mathrm{~S} \rightarrow 2 \mathrm{Na}_{2} \mathrm{~S}+\mathrm{Na}_{2} \mathrm{SO}_{3}+3 \mathrm{H}_{2} \mathrm{O} \\
& 3 \mathrm{Ca}(\mathrm{OH})_{2}+3 \mathrm{~S} \rightarrow 2 \mathrm{CaS}+\mathrm{CaSO}_{3}+3 \mathrm{H}_{2} \mathrm{O}
\end{aligned}
$$

Sodium or calcium sulphides open the skin epidermis and destroy the parasites.

\section{CHEMISTRY AND PHARMACY HISTORY IN THE SERVICE OF CHEMISTRY DIDACTICS.}

In the introduction of the article, we wrote about creating a mood. As a rule, Chemistry seems difficult for school students and therefore teachers have to constantly take care of creating and keeping that mood. There are a variety of methods for creating the mood $[16,17]$ and one of them is the technique of relating a specific topic to the history of Chemistry. If we manage to back up the historical background with chemical experiments, then students will most probably take an interest in chemistry. For instance, when studying the topic on "salts", "acids" or "metals", it should be exciting for the students to prepare ink with an old technique.

After the historical background, ink can easily be made by mixing tannin acid with iron sulphate. It would be an easy preparation of ink and the students will be able to write different words or even formulas on paper immediately after it gets slightly condensed. When studying the topic on "metals" we can link the colors of their ions to the color of paints, for instance: lead oxide was used in making a yellow pigment. In order to prove the yellow coloring of lead ion, an experiment can be conducted with potassium iodide and lead acetate. The latter was called "lead sugar" by the follower of Egyptian alchemist -

Zosimos of Panopolis, believing that salt had a sweet taste like sugar [18]. It will be useful if we provide students with information on lead harmfulness. Lead is a heavy metal and it can cause harm to the organism, as it can be accumulated in the body at the protein level. When studying the topic "Salts", we can decompose the malachite. In this way, we will overlap the topic "oxides", like water, carbon dioxide and copper (II) oxide are formed. The same experiment can be used for studying "the types of chemical reactions" in particular, 
"Decomposition Reaction". Mineral malachite is a complex copper salt and as shown from the upper part of the article, it was used for many purposes. Similarly, the historical material can be found for other minerals as well, for instance, on Lazurit, the same as Lapi Lazuliz [19,20], containing calcium, aluminum, silisium. When characterizing calcium oxide and hydroxide, we can remind the students about lime and the history of its use. When studying the topic of "indicators" ("acids", "hydroxides") a nice experiment called "chemical flower" can be conducted, where different indicators are placed in a Petri dish filled with isopropyl alcohol, next to which we put a small piece of sodium and watch the process of discoloration and ultimately make relevant conclusions. The indicator was discovered by Robert Boil, records about him can be found in the book by Vakhtang the VI. Such historical stories can be provided for any topic, making the lesson of chemistry much more interesting and multifarious.

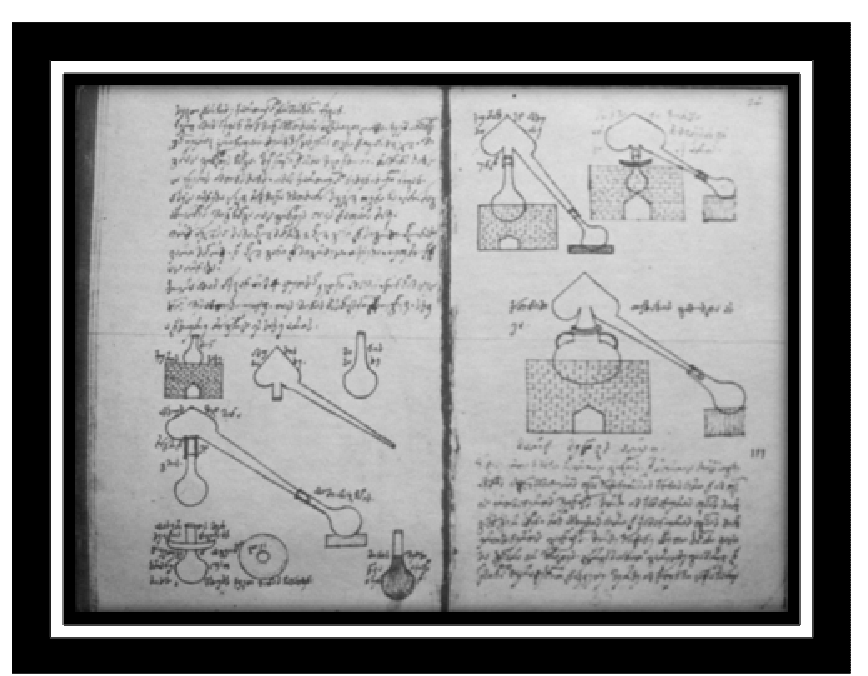

Figure 1. The book of Vakhtang the VI

\section{CONCLUSIONS:}

Thus, Chemistry has been developed in Georgia since ancient times. It was mainly used in craftsmanship and for household needs, though they didn't understand the chemical essence of the process of course. Everything was based on observation and experience. The book by Vakhtang VI is the most significant chemical thesis, where he almost perfectly describes various chemical experiments for that time. From the records, it becomes clear that the king himself conducts the experiments in the lab and in case of failure of any experiment, he honestly admits:
"I've done these and didn't get anything out of them".

The pharmacy was also well advanced in medieval period Georgia, as proved by archeological excavations and chemistry books have survived to our times. The list of Karabaddin (medical books) clearly shows that their authors were familiar with the records of Arab alchemistsphysicians and not only agreed with them but even expanded their prescriptions based on own observations.

For instance, when talking about treatment of joints in his medical book, the former Hodja agrees with Al-raz, that treatment with natural remedies is always better. In addition to various prescriptions, he also speaks about maize bran, as it prevents the spread of inflammatory processes. Indeed, bran (especially maize) contains rough fibers, that are not digested in the human body, they absorb inflammatory bacteria in intestines and do not allow them to spread. Joint pain is caused by inflammatory processes and age changes. Al-Razi didn't speak about bran, but instead, in case of joint paint, he would advise paying attention to the parasites spread in the abdominal cavity. Such details indicate that in Georgia they made use of already existing knowledge and developed a new one based on their own observations.

\section{REFERENCES:}

1. Khaukhchisvili, S., What are saying the ancient Greeks about Georgia?, Metsniereba. Tbilisi. 1964.

2. Greenberg, A., From Alchemy to Chemistry. John Wiley \&Sons.NH, 2007.

3. Djafaridze, O. Archaeological excavations in Georgia. University Press. Tbilisi. 1970.

4. Javakhishvili, I., The History of Georgian Nations. Tbilisi National Academy. Tbilisi. 2012.

5. Abuladze, I., The Dictionary of ancient Georgian language, Metsniereba., Tbilisi. 1973.

6. Javakhishvili, I., The History of Georgian Nations. National Academy., Tbilisi. 2012.

7. Aphakidze, A., The construction of ceramics in the ancient period of Kartli Kingdom The Works of Iv. Javakhishvili Institute of History, V. 2004.

8. Mroveli, L., Life of Kartli, Metsniereba. Tbilisi. 1955. 
9. Vakhtang VI, The Book of mixing oils and making chemistry. Printing house of Tbilisi University. Tbilisi. 1991.

10. Ugrelidze, N., Glass in ancient Georgia, Printing house of Tbilisi University. Tbilisi. 1961.

11. Bregvadze, D., Vakhtang VI in Iran. The work of Kutaisi State Pedagogical University, V. XXVI. \#10. 1963.

12. Atchariani, P., The Dictionary of Armenian Etimology, Metsniereba. Tbilisi. 1996.

13. Former Hodja, The Book of Medisine. Samshoblo. Tbilisi. 1936.

14. Kupatadze, K., Malazonia, D., The Overview of Chemical knowledge in Eighteent Century Georgia according to the Chemistry Book by King Vakhtang VI. Orbital: The Electronic Journal of Chemistry, Vol.8. \#3. 2016.

15. Menabde, L., Vakhtang VI (Life and Work). Printing house of Tbilisi University. 2011.

16. Uznadze, D.,Mood Theory, Metsniereba. Tbilisi. 1967.

17. Kupatadze, K., Histrory of Chemistry and Scientific Tourizm as a Means to Increase Students Motivation to Learn Chemistry. Journal Tche Quimica, \#22. 2014.

18. Azimov, A., History of Chemistry. Press "Мир". Moscow. 1983.

19. Karimov, U., The unknown work of Al-Rāzì "The great book of mystery". Tashkent, 1957.

20. Ferrario, G., Maimonides' Book on Poisons and the Protection Against Lethat Drugs. Cambridge Univrsitu Press. 2014. 